\title{
The Causal Link between FDI and Remittances in Kosovo, Switzerland, and Denmark
}

\author{
Kida Nakije (iD) https://orcid.org/0000-0002-2273-5679 \\ Assistant Professor Banking and Finance Department, College AAB, Pristina, Kosovo \\ e-mail: nakije.kida@aab-edu.net
}

\begin{abstract}
The pursuit of money and capital is a relentless endeavor of every economy. FDI is considered the engine of economic growth, while are remittances the increasingly the catalyst of the population's welfare. The purpose of the study is to analyze the answer about the relationship between remittances and FDI inflows in Kosovo, Switzerland and Denmark. Secondary data obtained from the World Development Indicators were, analyzed with the Ordinary Least Squares model and Granger Causality and processed with SPSS 21 technique. Measuring the correlation between variables, Foreign Direct Investment, GDP per capita growth, net migration, remittances, Gross Fixed Capital Formation, household consumption, and population number, give reliable results. Using remittances as a dependent variable, the first hypothesis has been partially confirmed, the most statistically significant and positive determinants that increase remittances are population, unemployment and migration and not other determinants. The regression results are unsatisfactory for the second hypothesis dependent variables Foreign Direct Investment the determinants are positive but not statistically significant, confirming that there are other factors that impact the increase of FDI inflows. The correlation matrix shows a high correlation between the variables. The Granger Causality model, through the Wald test, represents the cause. FDI does not cause remittances, but remittances cause FDI. A limitation of the study is the heterogeneity of the data and the countries in the sample. The results of the study will be of interest to government institutions in Kosovo to improve the business environment so that the country will become attractive to foreign investors who will bring capital and employment growth.
\end{abstract}

Keywords: FDI, remittances, panel data, OLS, Granger causality

JEL: F21, F33, E2, F24, R15 


\section{Introduction}

Capital formation is essential for a country's economic development and developing economies find it difficult to secure this capital (a problem that needs to be resolved). Development economies to solve the problem of lack of capital must benefit more and more from the inflow of FDI and remittances coming from developed countries. The creation of a good employment strategy in the countries of the European Union has attracted the labor force from developing countries. The focus of the study is remittances and FDI as providers of multiple benefits, technology transfer, new employment, innovative products and services, capital stock growth and consumption. It has been shown that the use of the appropriate study model and methodology are important determinants of the degree of differences reported, especially if the sample sites are of largely different.

For many years Kosovo topped the list of the most optimistic countries in the world, according to Gallup International research although it still suffers from considerable poverty (Global Happiness and Hope Index n.d.).

Furthermore, unemployment is a significant problem that encourages outward migration (BTI Transformation Index n.d.). Denmark was the happiest country in the world in 2017 (World Happiness Report 2021). Denmark while Switzerland is not only one of the most beautiful places on earth, it is one of the safest and most stable countries (Switzerland Rated One of the Safest Countries by DKV n.d.) Denmark. If we compare their growth paths, the indicators selected in the study are important factors of revenue growth, especially for Kosovo. Remittances are expected to be statistically significant for Kosovo, with rising unemployment a problem not only internally but also externally (Switzerland faces over 50.000 Albanians who have come to this country since 1968, first from Kosovo and latter from Albania, and have been successfully integrated). The opening of legal, long-term migration routes facilitates the lives of Kosovo citizens, while daily or weekly migration to Switzerland and Denmark will increase the country's income and create satisfaction for its citizens and foreigners.

A comparative analysis of the three countries will help us to understand a lot.

Economic growth has averaged around $4 \%$ for 15 years in Kosovo, driven by public investment supported by consumption and remittances and less by exports. However, it has failed to reduce high unemployment and youth emigration. In 2018, Kosovo reached a GDP of $\$ 7.6$ billion; however, its GDP per capita of only $\$ 4,108$ is insufficient to raise the living standard of the population (Kosovo Snapshot 2019). 2019 brought only $€ 254.6$ million in FDI (CBK 2020), which contributed only 3.04\% to GDP. The situation of Foreign Direct Investments it was also not satisfactory in 2020, with only €295.0 million). While the share of remittances in GDP in 2018 was 15.64\% (World Bank Group 2019) continuing with this trend in 2019 and 2020 (World Bank Group 2020). Gross Fixed Capital Formation (GFCF) contributes about 16\% to GDP while Household consumption increased to only 2.2\% in 2018 (World Bank Group 2019).

Denmark has an economy that continues to perform well. The annual GDP per capita growth in 2018 was $0.9 \%$, the share of FDI in GDP was $1.5 \%$, remittances contrib- 
uted only $0.4 \%$ to GDP, and GFCF annual growth was $5.1 \%$. householdl consumption had an annual growth of $2.3 \%$, while unemployment was low at $5.9 \%$ (World Bank Group 2019).

Switzerland has political and economic stability and efficient markets (globalEDGE n.d.). In 2018, the annual GDP per capita growth was $1.76 \%$, FDI contributed $9.6 \%$ to GDP, remittances contributed $0.35 \%$ to GDP, and GFCF had an annual growth of $1.78 \%$. The annual growth of household consumption was $1.04 \%$, and unemployment was only $4.79 \%$ (World Bank Group 2019).

The aim of the research is to find the determinants that increased FDI inflows and remittances in the three countries, with the aim of stimulating the independent macro-economic variables included in the study through the fiscal favoring that the government will do to increase FDI and remittancat.

A study conducted in Central and Eastern Europe found a positive impact of both FDI and remittances on GDP, but the impact of FDI is higher than that of remittances in all countries analyzed (Comes et al. 2018). Therefore, developing countries need to work harder on promotional strategies to attract FDI because of its positive impact on economic growth (Büthe and Milner 2008).

FDI has a higher impact on economic growth than remittances because most remittances come for consumption and rather than investment. For FDI, they come in the form of capital, knowledge, and expertise, and they lead to an increase in company productivity and technology transfer from foreign to domestic enterprises (Glass and Saggi 2002; Saggi 2002). However, some believe that the impact of FDI and remittances on the economic growth of the beneficiary country is conditioned by several factors.

According to Borensztein, De Gregorio, and Lee (1998), the impact of FDI on economic growth depends on the level of education and training of the workforce. The higher the level of qualification the workforce, the more FDI contributes to economic growth. By contrast, Blomstrom, Lipsey, and Zejan (1992) claim that FDI has a strong impact on economic growth if the beneficiary country is rich, whereas the level of qualification of the workforce is not significant.

The idea that the impact of FDI on economic growth is higher in developing countries is supported by Balasubramanyam, Salisu, and Sapsford (1996). According to Mottaleb (2007), the impact of FDI on economic growth was small in countries with low GDP per capita, poor education, little infrastructure, and low trade openness. By contrast, according to Carkovic and Levine (2005), FDI does not affect the economic growth of countries, regardless of their level of development. On the other hand, Beugelsdijk, Smeets, and Zwinkels (2008) support the view that the impact of FDI on economic growth in developing countries is unclear. But one thing that is clear is that FDI increases the capital of host countries just as remittances increase the consumption of host countries.

So, after FDI, remittances represent the second-most important source of funding for a country even though there are conflicting opinions in the literature. Discussions are made whether more remittances come in the form of capital transfer or income. 
Opinions differ on what impact remittances have on economic growth. Giannetti, Federici, and Raitano (2009), in a study on the eastern states of the European Union (Slovenia, Poland, the Czech Republic, and Hungary), demonstrated the existence of a link between remittances and the economic growth of the countries of origin. Barajas et al. (2009) analyzed the relationship between remittances and the level of economic growth in 84 countries in the period 1970-2004. The results show that workers' remittances have no impact on economic growth.

However, some point out that remittances increase household incomes and are therefore a powerful force against poverty in developing countries. Ratha (2013) claims that remittances positively impact the growth of incomes of the population, leading to a reduction in unemployment. A study of 71 developing countries found that a $10 \%$ increase in official international per capita remittances would produce a $3.5 \%$ drop in the share of people living in poverty (Adams Jr and Page 2005).

Some studies state that remittances tend to increase in times of economic change, political and civil crises, and natural disasters because migrants living abroad are emotionally attached to their families and are more loyal than other foreign investors. The results of a study by Mehedintu, Soava, and Sterpu (2019) found that remittances represent a relatively stable financial source for Romania and other developing countries in Europe, although their value tends to decrease, it is still though that remittances improve access to finance financial development and therefore stimulate economic growth.

However, one thing is clear. The "brain drain" of skilled workers is among the negative effects of remittances, and this is due to low incomes, high unemployment, and income inequality (Haller, Butnaru, and Butnaru 2018). Most studies focus on the microeconomic effect on remittance income and poverty in host countries, while the study by Bourdet and Falck (2006) focused on the macroeconomic impact of remittances on the real exchange rate in Cape Verde, by Portuguese immigrants living in USA Latin. The authors conclude that remittances create a kind of "Dutch Disease" effect and thus have the opposite effect on the competitiveness of the tradable sector.

In conclusion, we emphasize the need to: a) change domestic government policies that orient FDI and remittances to exports; b) limiting negative impact of remittances on the economy through the orientation of remittances for investment and not for consumption; c) eliminating the "Crowding out" effect of capital reinvestment in our home country that investors often do, and d) creating a good employment strategy in developing countries, to see the positive impact on economic growth.

\section{Literature review}

In general, remittances refer to 'money and goods transmitted to families by migrant workers working outside their home countries' (Adams 2009, p. 93; cited by Rahman and Fee 2014). However, the emigrants can transmit positive messages about the im- 
age of their home country or assist investors through information about their home country. Switzerland is a country where a large proportion of the Kosovo emigrants work in different jobs, while Denmark is less frequented. There are major differences between these three countries in terms of economic, social, and political development, this would be an impetus for Kosovo to follow them. These differences, to the detriment of Kosovo, are reflected in the investors' decisions. Investors prefer developing countries as "factory economy" while themselves prefer to be the "headquarters' economy" that govern production networks (Baldwin and Lopez-Gonzalez 2015, p. 29, 32). With $€ 254.6$ million of FDI inflows in 2019, Kosovo is neither a "factory economy" nor a "headquarters' economy".

According to Helbling and Leblang (2019, p. 1), immigration policies significantly affect immigration flows. The effects of restrictive immigration policies decrease when the unemployment level is high Brekke, Roed, and Schone (2016), highlighted the unprecedented number of asylum seekers Europe experienced in 2015. The results of their study related to asylum seekers point out that stricter asylum policy reduces the number of new asylum seekers, while Czaika and De Haas (2016) argued that migration flows decrease as travel visa requirements become more stringent.

However, remittances are a global phenomenon older than FDI, and they are quite widespread, especially in developing, transition, and poor countries. In the study by Javorcik et al. (2011), the results suggest that FDI in the USA is positively related to migrant remittances. The data show that the relationship between FDI and migration is stronger for tertiary education migrants (Javorcik et al. 2011). Chami, Fullenkamp, and Jahjah (2003) found that remittances have a negative impact on per capita income growth, reporting three facts: 1 ) most remittances are spent on consumption; 2) a small portion of remittance funds goes to saving or investing; 3) part of remittances goes to the construction of houses, or land, gold ornaments, which are not productive for the economy. Basnet and Upadhyaya (2014) used data for 35 middle-income countries from Latin America, Asia-Pacific, and Africa. The estimated results give no importance to remittances in attracting FDI when all regions are included. However, when the estimates are done according to geographical division, remittances positively affect African countries, no significant effects on Latin American countries, and a negative effect on the Asia-Pacific region. Coon and Neuman (2016), in their study of a panel of 118 countries between 1980 and 2010 using the Random Effects model, found a positive and significant effect of FDI inflows on remittances. They also found a strong relationship with low-income countries. Buch and Kuckulenz (2010) found that remittance shipments respond more to demographic variables, while private equity flows respond more to macroeconomic conditions.

The greatest effects of remittances are on reducing poverty through increased consumption. The effects of remittances in Kosovo are positive even though active workers are being lost every day, but we suffer from low FDI. 


\section{The a objectives, hypotheses, and approach to the study model}

The objective of this study, is to identify the determinants of Foreign Direct Investment and Remittances in Kosovo, Switzerland and Denmark.

The objectives extend even further:

- To analyze the current trend of FDI inflows and remittances to Kosovo, Switzerland, and Denmark;

- To analyze the relationship between Foreign Direct Investment, GDP per capita growth, gross fixed capital formation, household consumption, population size, and growth of remittance inflows in Kosovo, Switzerland, and Denmark (correlation between variables);

- To measure the impact of FDI, GDP per capita growth, GFCF, household consumption, migration, and population size on the growth of remittances in Kosovo, Switzerland, and Denmark and vice versa - the impact of these variables on FDI.

Hypothesis H1: The remittance flow growth in Kosovo, Switzerland, and Denmark depends on FDI inflow growth, GDP per capita growth, GFCF, household consumption, and the population size in these countries.

Hypothesis 2: The grow th of FDI inflows in Kosovo, Switzerland, and Denmark depends on Remittances, GDP per capita growth, GFCF, household consumption, and population size in these countries.

Hypothesis H3: The relationship between FDI, remittances, net migration, GDP per capita, GFCF, household consumption, and population size in Kosovo, Switzerland, and Denmark is positive.

The approach to the study model: To make this study more interesting, the variables selected are those that highlight these differences through combining countries with different levels of development.

The following variables are included in the hypothesis:

- Dependent variables in the two equations: Remittance (REM), dependent (H1); FDI, dependent on equation (H2).

- Independent variables: Unemployment (UN); GDP per capita (GDPpc), Net migration (NM); Gross Fixed Capital Formation _ annual growth (GFCF); Household Consumption _ annual growth (HC); Population size(PS).

- The relationship between variables was also measured (H3).

The panel of 3 countries was evaluated for the period 2004-2018, using the Ordinary Least Squares (OLS) and Granger Causality (GC) models, with follow-up tests to increase the study's reliability.

To test the hypotheses, the estimation was done through the model in Eq. 1, Eq. 2, and Eq. 3, obtained in the paper by Coon and Neumann (2016, p. 9):

$$
\mathrm{Rit}=\beta 0+\beta_{1} \mathrm{FDI}_{\mathrm{it}}+\beta_{2} \text { Net migration }_{\mathrm{it}}+\Gamma \mathrm{Z}_{\mathrm{it}}-1+\Phi \mathrm{X}_{\mathrm{it}}+\epsilon \epsilon_{\mathrm{it}}+u_{\mathrm{i}} \text {, }
$$


where $\mathrm{R}_{\mathrm{it}}$ stands for the remittances sent by country (i). FDI is FDI net inflows to countries in year $(\mathrm{t})$; emigration is net migration in the country; $\mathrm{Z}$ is a vector of the three variables related to the unemployment rate in the country, population size, and GDP per capita growth (annual \%).

Equ. (1) also includes $\mathrm{X}_{\mathrm{it}}$ as a representative of the additional control variables as determinants of remittances such as Gross fixed capital formation and household consumption.

In the empirical model (Eq. 2), remittances are a dependent variable. Considering the migrants' proximity to foreign investor partners, FDI is placed in the second hypothesis (Eq. 3), while the other variables are independent.

Measuring the relationship between these variables was considered necessary. Thus, to identify the causal direction between these variables, the Granger model (Granger 1969) and the following Vector Auto Regression (VAR) framework were used in a panel proposed by Holtz-Eakin, Newey, and Rosen (1988), cited in Coon and Neumann (2016, p. 10), modified by several variables (population size, unemployment, GFCF, net migration, and household consumption) smilar to Pesaran, Shin, and Smith (2001, pp. 303-304), who used the following model to see whether the relationship between variables is present to reject the null hypothesis:

$$
\begin{gathered}
\left.\mathrm{R}_{\{\mathrm{i}, \mathrm{t}\}}=\mathrm{ai} \sum_{k=1}^{p} Y k^{R}+, \mathrm{t}-k\right\}+\sum_{k=1}^{p} B k^{F D I}\{\mathrm{i}, \mathrm{t}-\mathrm{k}\}+_{, \mathrm{t}} \\
\left.\mathrm{FDI}_{\{\mathrm{i}, \mathrm{t}\}}=\mathrm{ai} \sum_{k=1}^{p} Y k^{F D I}+, t-k\right\}+\sum_{k=1}^{p} B k^{R}\{\mathrm{i}, \mathrm{t}-\mathrm{k}\}+_{, \mathrm{t}}
\end{gathered}
$$

$\mathrm{H} 0: \theta 0=0$, against $\mathrm{H1}: \theta 0<0 ; \mathrm{H} 0: \beta \mathrm{k}=0, \forall \mathrm{k}=1$, in favor of the alternative hypothesis $\mathrm{H} 1 . \mathrm{H} 1: \beta \mathrm{k} \neq 0$.

The results of equations (2) and (3) are estimated with the OLS model, which measures the impact of all above-mentioned variables on remittances as a dependent variable in equation 2, and the impact of the same independent variables on FDI dependent variable in equation 3.

The Granger causality test, based on the Wald relevance test, was used to determine the direction of a causal relation between Foreign Direct Investment (FDI) and Remittances (REM) and vice versa. It also measures the relationship of FDI and remittances separately with other control variables, Population size (PS), Unemployment (UN), Gross Fixed Capital Formation (GFCF), Net migration (NM), and Household Consumption (HC). The data for the empirical econometric analysis were obtained from World Development Indicators (WDI) and are in US\$. The data are annual, from 2004-2018. Migration is measured as the number of people at the end of the year that migrated abroad from country (i). For the variables presented earlier, we have $(\mathrm{k}+1)=8$ variables. The SPSS 21 technique was applied to all tests, including the testing of the Granger Causality model. 


\section{The results of the study}

The descriptive statistics of the panel data in Table (1) provide a statistical summary of the mean distribution of each variable according to the analyzed OLS model. The data include macroeconomic variables included in the model. It also includes the number of observations for each variable, mean, distribution from the mean, and the minimum point that make the interval around which the variables' values fluctuate. From the table, we draw the following conclusions:

First, the model finds that the variable values of the annual GDP per capita (GDPpc) around the mean are more concentrated than the other variables because the value distribution is 2.05 units out of the mean 1.72 units; this distribution is the lowest.

Table 1. Derscriptive statistics (WDI, 2019, US\$), 2004-2018

\begin{tabular}{|l|c|c|c|c|c|}
\hline Variable & Obs & Mean & Std. & Dev. & Min \\
\hline PS & 45 & 5094558 & 2571530 & 1704622 & 8516543 \\
\hline GDPpc & 45 & 1.727301 & 2.057824 & -5.413992 & 6.427747 \\
\hline FDI & 45 & 3.862642 & 5.073199 & -9.592785 & 16.82878 \\
\hline REM & 45 & 5.814232 & 7.874408 & .2518616 & 20.03687 \\
\hline GFCF & 45 & 3.943085 & 6.877594 & -13.63129 & 28.86522 \\
\hline UN & 45 & 16.23625 & 16.04212 & 4.1161 & 47.5 \\
\hline HC & 45 & 2.99047 & 3.338539 & -3.432123 & 12.98892 \\
\hline NM & 12 & 133627.6 & 147603.3 & -16381 & 397267 \\
\hline
\end{tabular}

Note: Results are obtained by SPSS 21

Source: all tables and figures in the study were compiled by the author.

The second best variable by distribution after the annual GDP per capita growth is the Household Consumption (HC). It has an average of 2.99 units with an average distribution of 3.38 units, indicating that even in this case, the distribution is concentrated during the period of analysis. In FDI, the value distribution is 5.07 units out of an average of 3.86 units. This indicates that these variables have a concentrated distribution throughout the analyzed period (2004-2018). In (GCFC), the distribution of values is 6.87 units out of an average of 3.94 units.

This indicates that these variables have a concentrated distribution throughout the analyzed period (2004-2018).

The same conclusion is also reached for the unemployment and remittances variables, but not for population (an average of 5094558, with a high standard deviation of 2571530) and migration (an average of 133627.6 with a standard deviation of 147603.3), for which tests of the normal distribution of the average will be performed. The above findings help us to conclude that further interpretation of the variables by the econometric model will be highly reliable because the values of their variables have a concentrated distribution around the average. From the above results, we see significant differences between the countries included in the research, in all the factors involved 
Based on the descriptive analysis (supplementary annex, tables 1a), the results presented are for the economies of the three countries. The average GDP per capita, FDI, and remittances in Switzerland as an absolute value are higher than in Kosovo. However, if measured as a percentage of GDP, for 15 years, Kosovo has led with remittances, from 15 to $20 \%$. Kosovo has the highest unemployment rate (maximum $46.3 \%$ in 2007 and minimum $27.31 \%$ in 2018) between the three countries, while both Switzerland and Denmark have low unemployment rates (from $4.1 \%$ to $4.9 \%$ in Switzerland, and from 5.5\% to 7.2\% in Denmark) between 2004 and 2018.

The household consumption statistics as a \% of GDP are interesting. Kosovo has a higher household consumption in 2004 of $13 \%$ and the lowest of $2 \%$ in 2017. In Denmark, household consumption is at a relative minimum value of $0.27 \%$ of GDP and a maximum of $4.6 \%$, while Switzerland ranges from 1.1 to $2.6 \%$. This means that the economy of Kosovo grew mostly from household consumption and remittances, which is a short-term growth. By comparison, the long-term growth in Switzerland and Denmark is through other indicators and less from remittances and household consumption. Both migration and unemployment variables make Kosovo first place compared to the two countries under study.

The results of the econometric evaluation are presented starting with the descriptive statistics in Annex A - Table 1a, the OLS method - Tables 2, 3, 4, 5, and 6, and Granger Causality - Tables 7 and 8. In Annex B, Tables 1b and 1c, the Anova One Way test is used to compare the three countries in terms of FDI and Remittances, and the Granger Causality test is in Table $8 \mathrm{a}$.

In Appendix B, Table $1 \mathrm{~b}$ measures the difference between the three countries regarding FDI and shows there is a statistically significant difference between the three countries $(\mathrm{F}=5.49$, $\mathrm{p}$-value $=.007<0.1 \%)$. Differences were found between Kosovo and Denmark $(\mathrm{MD}=5.2876$, $\mathrm{p}$-value $=.009)$, and between Denmark and Switzerland $(\mathrm{MD}=4.23212, \mathrm{p}$-value $=.048)$, but no significant differences were found between Kosovo and Switzerland $(\mathrm{MD}=-1.05465$, $\mathrm{p}$-value $=.900)$.

In appendix B, Table $1 \mathrm{c}$ is measures the difference between the three countries regarding Remitances. It shows that there are no statistically significant differences between the three countries in terms of REM ( $F=970.25$, p-value $=0.000)$, between Kosovo and Denmark $(\mathrm{MD}=16.3605$, $\mathrm{p}$-value $=.000)$, between Kosovo and Switzerland $(\mathrm{MD}=0.037888$, p-value $=.1000)$, or between Denmark and Switzerland $(\mathrm{MD}=-16.3226, \mathrm{p}$-value $=0.00)$.

\section{Ordinary Least Squares (OLS) model}

Ordinary Least Squares (OLS) analysis was used to determine the statistically significant difference between the three countries (Tables 2, 4, and 5). The following results show that a significant statistical difference was found in all variables, except for Gross fixed capital formation. 


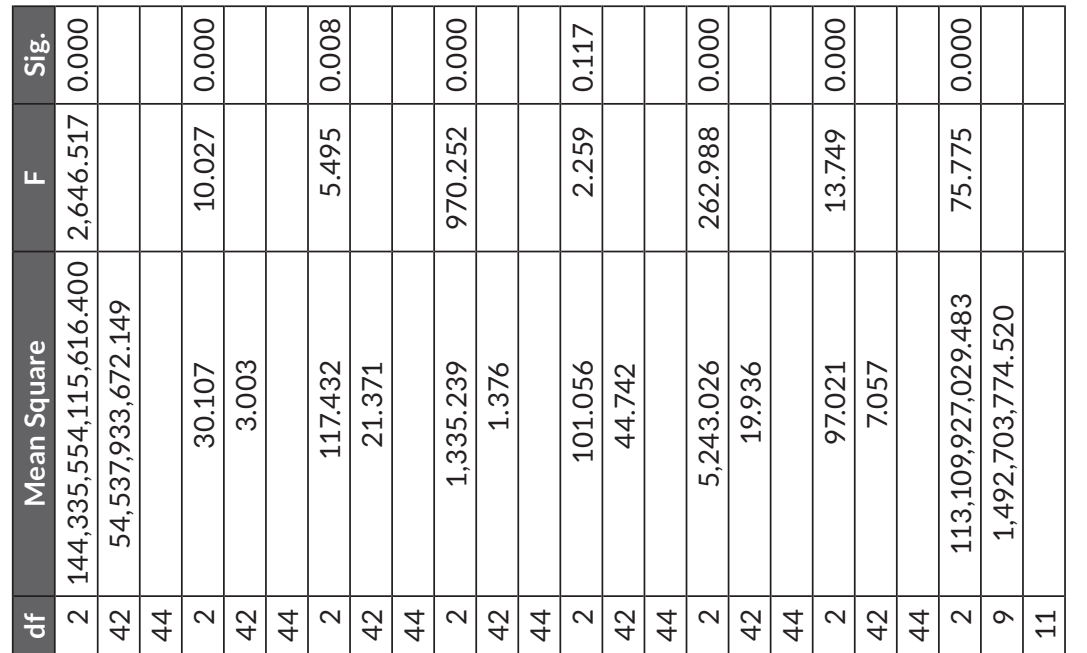

이일

究

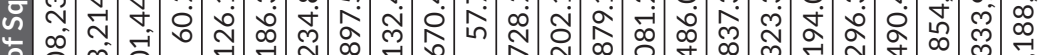

t) 
In Table 3, the normality test was performed.

Table 3. The test normality

\begin{tabular}{|l|c|c|c|c|c|c|}
\hline \multicolumn{7}{|c|}{ Tests of Normality } \\
\hline & \multicolumn{2}{|c|}{ Kolmogorov-Smirnov } & \multicolumn{3}{c|}{ Shapiro-Wilk } \\
\cline { 2 - 7 } & Statistic & Df & Sig. & Statistic & Df & Sig. \\
\hline Population size & 0.223 & 12 & 0.103 & 0.853 & 12 & 0.039 \\
\hline GDP per capita growth (annual \%) & 0.167 & 12 & $0.200 *$ & 0.946 & 12 & 0.581 \\
\hline Foreign direct investment, net inflows (\% of GDP) & 0.216 & 12 & 0.127 & 0.943 & 12 & 0.536 \\
\hline Remittances, received (\% of GDP) & 0.414 & 12 & 0.000 & 0.650 & 12 & 0.000 \\
\hline Gross fixed capital formation (annual \% growth) & 0.352 & 12 & 0.000 & 0.732 & 12 & 0.002 \\
\hline Unemployment (\% of total labor force) & 0.374 & 12 & 0.000 & 0.729 & 12 & 0.002 \\
\hline Households consumption (annual \% growth) & 0.252 & 12 & 0.034 & 0.727 & 12 & 0.002 \\
\hline Net migration & 0.239 & 12 & 0.058 & 0.858 & 12 & 0.047 \\
\hline
\end{tabular}

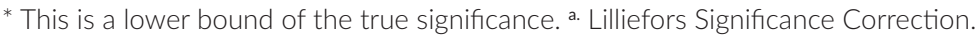
Parametric data: $p>0.5 \%$; Nonparametric data: $p<0.5 \%$.

Source: World Development Indicators (WDI), author's own elaboration.

The impact of independent variables on the dependent variable, Remittances, is tested to reach a final conclusion:

Hypothesis H1: The remittance flow growth in Kosovo, Switzerland, and Denmark depends on FDI inflow growth, GDP per capita growth, Gross fixed capital formation, household consumption, and population size in all countries.

The results in Table 4 below show that there is a positive relationship between remittances and unemployment, $(\beta=0.731, \mathrm{p}=.013, \mathrm{p}<.05 \%)$, which means that statistically, the growth of remittance flows in Kosovo, Switzerland, and Denmark is affected by rising unemployment

Empirical equation:

$$
\begin{gathered}
\mathrm{R}_{\{i, t\}}=\text { cons } 0.023 \text { - PS.it } .962+\text { GDPpc.it } 0.721 \text { - FDIit } 0.197- \\
\text { GCFCit } 0.045 \text { - UNit } 0.364 \text { - HCit } 0.258 \text { + NM.it. } 1.64
\end{gathered}
$$

There is a close but statistically insignificant impact or population size $(\beta=-0.649$, $\mathrm{p}=.071, \mathrm{p}>.05 \%)$ and net migration $(\beta=0.302, \mathrm{p}=.093, \mathrm{p}>.05 \%)$, while in other cases, the statistics are insignificant and the coefficients are negative, such as GDP per capita growth $(\beta=0.107, \mathrm{p}=.169, \mathrm{p}>.05 \%)$, Foreign direct investment $(\beta=-0.116, \mathrm{p}=.278$, $\mathrm{p}>.05 \%)$, Gross fixed capital formation (\% GDP) $(\beta=-0.048, \mathrm{p}=.588, \mathrm{p}>.05 \%)$ and household consumption (\% GDP) $(\beta=-0.110, \mathrm{p}=.192, \mathrm{p}>.05 \%)$. From another point of view, the correlation of these factors has a positive relation in general with remittances $(\mathrm{rho}=.996, \mathrm{R} 2=.993, \mathrm{p}$-value $=.000, \mathrm{p}<.01 \%)$, i.e., it is statistically significant at the $1 \%$ level of confidence. 
The growth of remittance flows in Kosovo, Switzerland, and Denmark depends largely on high unemployment and partly on population growth and migration growth.

Table 4. The Coefficients

\begin{tabular}{|c|c|c|c|c|}
\hline \multirow{2}{*}{ Independent variables } & \multicolumn{4}{|c|}{ Model (1) } \\
\hline & Beta & S.H. & $\beta$ & Sig. \\
\hline Population size & $-1.962 \mathrm{E}-6$ & 0.000 & -0.649 & 0.071 \\
\hline GDP per capita growth (annual \%) & 0.721 & 0.430 & 0.107 & 0.169 \\
\hline Foreign direct investment, net inflows (\% of GDP) & -0.197 & 0.157 & -0.116 & 0.278 \\
\hline Gross fixed capital formation (annual \% growth) & -0.045 & 0.076 & -0.048 & 0.588 \\
\hline Unemployment (\% of total labor force) & 0.364 & 0.085 & 0.731 & 0.013 \\
\hline Households consumption (annual \% growth) & -0.258 & 0.165 & -0.110 & 0.192 \\
\hline Net migration & $1.640 \mathrm{E}-5$ & 0.000 & 0.302 & 0.093 \\
\hline $\mathrm{R}$ & \multicolumn{4}{|c|}{0.996} \\
\hline $\mathrm{R}^{2}$ & \multicolumn{4}{|c|}{0.993} \\
\hline$\Delta \mathrm{R}^{2}$ & \multicolumn{4}{|c|}{0.979} \\
\hline $\mathrm{F}$ & \multicolumn{4}{|c|}{76.074} \\
\hline ANOVA (Sig.) & \multicolumn{4}{|c|}{0.000} \\
\hline
\end{tabular}

Source: World Development Indicators (WDI), author's own elaboration.

The second hypothesis is tested below, where it measures the impact of the independent variables on the dependent variable, Foreign Direct Investment:

Hypothesis 2: The growth of FDI inflows in Kosovo, Switzerland, and Denmark depends on Remittances, GDP per capita growth, Gross fixed capital formation, household consumption, and population size.

Empirical equation:

FDI $i, t\}=$ cons $0.197-$ GDPpc.it 5.207 + REM it $0023-$

GCFCit $1.437+$ UNit $0.091+$ HCit 0.43 - NMit. 0.503

FDI - the dependent and other independent variables (Table 5). Based on the results below, we can state that there were no cases with any significant and positive effects on $p$-value and coefficients in the variables of GDP per capita growth $(\beta=-.2 .192$, $\mathrm{p}=.313)$, Remitances $(\beta=.006, \mathrm{p}=.949)$, Gross fixed capital formation $(\beta=-2.431$, $\mathrm{p}=.270)$, Unemployment $(\beta=.164, \mathrm{p}=.723)$, Households consumption $(\beta=1.467$, $\mathrm{p}=.287)$ and Net migration $(\beta=-0.362, \mathrm{p}=.320)$. Meanwhile we have a high positive correlation of .919, but it is not statistically significant ( $\mathrm{p}$-value $=.146$ ).

From these results, we can say that the growth of FDI inflow in Kosovo, Switzerland, and Denmark does not depend on Remittances, GDP per capita growth, Gross fixed capital formation, household consumption, or population size it depends on other factors not explored in this study. 
Table 5. The Coefficients

\begin{tabular}{|c|c|c|c|c|}
\hline \multirow{2}{*}{ Independent variables } & \multicolumn{4}{|c|}{ Model (2) } \\
\hline & Beta & S.H. & $\beta$ & Sig. \\
\hline GDP per capita growth (annual \%) & $-5.207 E-6$ & 0.000 & -2.912 & 0.313 \\
\hline Personal remittances, received (\% of GDP) & 0.023 & 1.517 & 0.006 & 0.949 \\
\hline Gross fixed capital formation (annual \% growth) & -1.437 & 1.145 & -2.431 & 0.270 \\
\hline Unemployment (\% of total labor force) & 0.091 & 0.210 & 0.164 & 0.723 \\
\hline Households consumption (annual \% growth) & 0.432 & 0.499 & 1.467 & 0.287 \\
\hline Net migration & -0.503 & 0.506 & -0.362 & 0.320 \\
\hline $\mathrm{R}$ & \multicolumn{4}{|c|}{0.919} \\
\hline $\mathrm{R}^{2}$ & \multicolumn{4}{|c|}{0.844} \\
\hline$\Delta R^{2}$ & \multicolumn{4}{|c|}{0.571} \\
\hline $\mathrm{F}$ & \multicolumn{4}{|c|}{3.093} \\
\hline ANOVA (Sig.) & \multicolumn{4}{|c|}{0.146} \\
\hline
\end{tabular}

Source: World Development Indicators (WDI, 2019), author's own elaboration.

In the correlation matrix in Table 6, we find that the correlation between variables, and between population and other variables, has a high negative but statistically significant correlation.

Table 6. The correlation matrix between variables

\begin{tabular}{|c|c|c|c|c|c|c|c|c|}
\hline Variable & PS & GDPpc & FDI & REM & GFCF & UN & $\mathrm{HC}$ & NM \\
\hline PS & 1 & & & & & & & \\
\hline \multirow{2}{*}{ GDPpc } & $-0.512^{* *}$ & 1 & & & & & & \\
\hline & 0.000 & & & & & & & \\
\hline \multirow{2}{*}{ FDI } & -0.149 & 0.187 & 1 & & & & & \\
\hline & 0.330 & 0.219 & & & & & & \\
\hline \multirow{2}{*}{ REM } & $-0.913^{* *}$ & $0.582^{* *}$ & $0.324^{*}$ & 1 & & & & \\
\hline & 0.000 & 0.000 & 0.030 & & & & & \\
\hline \multirow{2}{*}{ GFCF } & -0.284 & $0.519^{* *}$ & 0.214 & $0.346^{*}$ & 1 & & & \\
\hline & 0.059 & 0.000 & 0.159 & 0.020 & & & & \\
\hline \multirow{2}{*}{ UN } & $-0.906^{* *}$ & $0.557^{* *}$ & $0.333^{*}$ & $0.981^{* *}$ & $0.374^{*}$ & 1 & & \\
\hline & 0.000 & 0.000 & 0.025 & 0.000 & 0.011 & & & \\
\hline \multirow{2}{*}{$\mathrm{HC}$} & $-0.580^{* *}$ & $0.598^{* *}$ & 0.195 & $0.675^{* *}$ & 0.142 & $0.638^{* *}$ & 1 & \\
\hline & 0.000 & 0.000 & 0.200 & 0.000 & 0.351 & 0.000 & & \\
\hline \multirow{2}{*}{ NM } & $0.887^{* *}$ & -0.342 & -0.546 & $-0.683^{*}$ & -0.408 & -0.687 & -0.420 & 1 \\
\hline & 0.000 & 0.277 & 0.066 & 0.014 & 0.187 & 0.014 & 0.174 & \\
\hline
\end{tabular}

Standard errors in parentheses; ${ }^{*} p<0.10,{ }^{* *} p<0.05,{ }^{* * *} p<0.01$

Source: author's own elaboration.

In the first case, we see that the correlation between population size and GDP per capita growth is statistically significant but negative $\left(\mathrm{rhi}=-0.512^{* *}\right.$, $\mathrm{p}$-value $=.000$ ). The same is true for remittances (rho $=-.913^{* *}$, p-value $=.000$ ), and Unemployment 
(rho $=-.906^{* *}, \mathrm{p}$-value $\left.=.000\right)$. The relationship between population and households consumption (rho $=-0.580^{\star *}, \mathrm{p}$-value $=.000$ ) is negative but statistically significant, while the correlation between population and migration is statistically significant $\left(\right.$ rho $=0.887^{* *}$, p-value $\left.=.000\right)$.

GDP per capita growth has a positive and statistically significant correlation with remittances $\left(\mathrm{rho}=.582^{\star *}, \mathrm{p}\right.$-value $\left.=.000\right)$, gross fixed capital formation $\left(\mathrm{rho}=.519^{\star *}\right.$, $\mathrm{p}$-value $=.000)$, unemployment $\left(\right.$ rho $=.557^{\star *}$, p-value $\left.=.000\right)$ and households consumption (rho $=.598^{\star *}, \mathrm{p}$-value $\left.=.000\right)$. There is a positive and statistically significant relationship between Foreign Direct Investment, net inflows with rremittances $\left(\right.$ rho $=.324^{\star *}, \mathrm{p}$-value $\left.=.030\right)$ and Unemployment, $\left(\right.$ rho $=.333^{\star *}, \mathrm{p}$-value $\left.=.025\right)$, which means the higher the volume of inflows of FDI, the higher the remittances and the lower the unemployment in the country. Remittances have a positive and significant relationship with Gross fixed capital formation (rho $=.346^{* *}, \mathrm{p}=.020$ ), unemployment $\left(\right.$ rho $=.981^{* *}, \mathrm{p}$-value $\left.=.000\right)$ and households consumption (rho $=.675^{\star *}$, $\mathrm{p}$-value $=.000)$. So, high remittances help the fixed capital, reduce unemployment, and increase households consumption. The negative and statistically significant correlation of remittances with migration ( $\mathrm{rho}=-.683^{\star *}$, $\mathrm{p}$-value $=.014$ ) means that the more remittances the migrants bring in, the less their family members emigrate.

\section{Granger Causality test model}

Since all the series are integrated in the same order, which is a necessary condition for standard testing of integration (Engle and Granger) to be measurable, we note that the two hypotheses are not rejected: Remittances bring FDI.

Hypothesis H3: The relationship between FDI, remittances, net migration, GDP per capita, GFCF, household consumption, and population size in Kosovo, Switzerland, and Denmark is positive.

Table 7. Granger Causality (Wald test statistics)

\begin{tabular}{|c|c|c|c|c|c|c|c|c|}
\hline Equation & Excluded & $F$ & Df & Df_r & Prob-F & R-sq & $P-F$ & Decision \\
\hline GDPpc & REM & .09752 & 1 & 10 & 0.7612 & \multirow[t]{3}{*}{0.7612} & \multirow[t]{3}{*}{.608} & \multirow[t]{3}{*}{ Reject } \\
\hline GDPpc & FDI & .47359 & 1 & 10 & 0.5070 & & & \\
\hline GDPpc & ALL & .24426 & 2 & 10 & 0.7878 & & & \\
\hline Remittance & GDP & 1.2088 & 1 & 10 & 0.2973 & \multirow[t]{3}{*}{0.8166} & \multirow[t]{3}{*}{.000} & \multirow[t]{3}{*}{ Accept } \\
\hline Remittance & FDI & 2.1363 & 1 & 10 & 0.1746 & & & \\
\hline Remittance & ALL & 1.4411 & 2 & 10 & 0.2819 & & & \\
\hline FDI & GDP & .99772 & 1 & 10 & 0.3414 & \multirow[t]{3}{*}{0.2543} & \multirow[t]{3}{*}{.393} & \multirow[t]{3}{*}{ Reject } \\
\hline FDI & REM & 1.5369 & 1 & 10 & 0.2434 & & & \\
\hline FDI & ALL & 1.5145 & 2 & 10 & 0.2664 & & & \\
\hline
\end{tabular}

Source: author's own elaboration.

The Wald test Was also performed, and the final values show a one-way correlation - remittances bring FDI while FDI does not bring remittances. 
Table 8. Granger Causality (Wald test statistic) $\left[X^{2} 0.05=0.996\right.$ (3df)]

\begin{tabular}{|c|c|c|c|}
\hline Ha: FDI not causes Remittances & $\mathbf{R}^{2}$ & Ha: Remittances cause FDI & $\mathbf{R}^{2}$ \\
\hline $0.393^{* *}$ & 0.555 & $0.000^{* *}$ & 0.996 \\
\hline
\end{tabular}

Source: World Development Indicators (WDI, 2019), author's own elaboration.

\section{Discussion of the study results}

It began from the descriptive statistical analysis to estimate the distribution of values in units from average to unit, as well as the measurement of minimum values. The multiple regression performed with the OLS model measured the impact of independent variables on the dependent variable, in the first case the dependent FDI while in the second case the remittances are presented as the dependent variable. Correlation analysis measured the relationship between variables. The Granger Causality model (1969) was applied to measure the cause of the relationship between variables. The panel results show that there are very large differences between countries, and tha all variables have important statistical significance except CGFC. The normality test was also performed (Table 3).

As we can see from Table 4, regarding hypothesis 1, migrant remittances are the dependent variable, all other variables are independent. The results of the analysis found a positive relationship between Remittances and Unemployment, $(\beta=0.731, p=.013$, $\mathrm{p}<.05 \%$ ), which indicates statistically that unemployment has an increasing impact on remittances to Kosovo, Switzerland, and Denmark. Population growth $(\beta=-0.649$, $\mathrm{p}=.071, \mathrm{p}>.05 \%)$ and migration $(\beta=0.302, \mathrm{p}=.093, \mathrm{p}>.05 \%)$ have a close but statistically insignificant impact on remittances. Meanwhile, GDP per capita growth (annual \%) $(\beta=0.107, p=.169, p>.05 \%)$, FDI $(\beta=-0.116, p=.278, p>.05 \%)$, GFCF (annual $\%$ growth) $(\beta=-0.048, p=.588, p>.05 \%)$ and Households consumption $(\beta=-0.110$, $\mathrm{p}=.192, \mathrm{p}>.05 \%)$ did not affect the remittance inflow growth.

As we can see from Table 5, for Hypothesis 2, FDI dependent variables - based on the results, we can say that there were no cases with any positive effects on coefficients and $\mathrm{p}$-value, although there was a high positive correlation of $\mathrm{R}^{2}=.919$, but a not statistically significant $\mathrm{p}$-value $=.146$. From these results, we can say that the growth of FDI inflows in Kosovo, Switzerland, and Denmark does not depend on remittances, GDP per capita growth, Gross fixed capital formation, household consumption, migration, or population size. It is estimated that the statistically insignificant effect of the independent variables on the attraction of FDI flows as a dependent variable is related to the theoretical FDI framework that not all economic indicators attract FDI. However, the Kolmogorov-Smirnov and Shapiro-Wilk normality tests show that population, GDP per capita, and FDI are statistically insignificant although positive, which means that there are other indicators that have not been analyzed that may attract FDI. This indicates that sample countries have large variations in these variables due to the specific economic conditions of each country. 
From another point of view, these factors have a positive correlation in general with remittances (rho $=.996, \mathrm{R}^{2}=.993, \mathrm{p}$-value $=.000, \mathrm{p}<.01 \%$ ). So, statistically, at the $1 \%$ level of confidence, the remittance flow growth in Kosovo, Switzerland, and Denmark is statistically significant, being largely dependent on unemployment and partly dependent on FDI inflow growth, GDP per capita growth, Gross fixed capital formation, household consumption, migration, and population size. The high unemployment rate in Kosovo has influenced the results of the study, which presents the unemployment variable as the key factor that attracts remittances to the three countries grouped as a sample.

In the empirical analysis, Adenutsi (2014) included 36 countries for the period 1980-2009. It was found that the flow of employee compensation and employee remittances is affected by the macroeconomic conditions of the host country. This is similar to our study, where the high level of remittances in Kosovo results from the low level of economic development, migration, and high unemployment there. These factors influenced the results of the study despite the developed countries being included in the sample. Also, our results are somewhat similar to the results of Palamuleni (2018), who showed that remittance flows have small, positive effects on FDI that vary by region and country. In particular, positive relationships are strong in African countries and countries that receive high shipments, but not for Asian and Latin American countries. While it is contrary to our results, the causality test suggests a two-way relationship. in our study, FDI does not cause remittances; remittances cause FDI.

As we can see from the Granger Causality test in Table 7 and the Wald test in Table 8a (in Annex B), the third hypothesis is upheld, further reinforcing the belief that remittances bring in FDI $\left(R^{2}=0.0996\right.$ and $\left.p=0.000\right)$. While Foreign Direct Investment not statistically significant $\left(\mathrm{R}^{2}=0.555\right.$ and $\left.\mathrm{p}=0.3380\right)$, to bring remittances to Kosovo, Switzerland, and Denmark.

\section{Conclusions}

The research finds that the remittance inflow growth in Kosovo, Switzerland, and Denmark, as shown in equation (2), does not depend on FDI, GDP per capita, or GFCF; it depends on unemployment, population size, and migration. The FDI inflow growth, as shown in equation (3), also does not depend on the study variables. There are other factors that drive FDI flows in these three countries. In the matrix in Table 6, GDP per capita growth is negatively correlated with population size; the more the population grows, the lower the GDP per capita. Remittances are statistically significant but negatively correlated with the population, while they are positively correlated with robust statistical significance with GDP and FDI.

Another positive correlation is the domestic investment with GDP and remittances. Unemployment has also been shown to be statistically significant but negative. lastly, household consumption has a statistically significant but negative relationship with 
population size, while there is a positive and statistically significant relationship with GDP per capita, remittances, and unemployment. In Kosovo, 16\% of GDP is supplemented by remittances, making migrants a short-term stabilizing factor to the economy. In the future, they can also be considered attractive to foreign investors, either throughpartnerships or through the social relations they have created. In 2018, the remittances brought to Switzerland were $0.35 \%$ of GDP; in Denmark, remittances brought in were only $0.38 \%$ of GDP the same year. Even from the descriptive analysis results, it is clear that remittances are still decreasing in countries with political, financial, social, and economic stability.

This is confirmed by analyzing the results. Low remittances, low unemployment, and rising FDI in Denmark and Switzerland did not change the statistical significance of the study variables. With a greater variety of data sets, the differences between with countries are clearly expressed and this is made possible by the technique of econometric evaluation and specification, and even the list of regressors included in the equation created the reliability of the results.

So, when there are differences between countries (such as Kosovo), in the short term, they cannot catch up with countries like Denmark and Switzerland. It is seen that not all variables are selected as appropriate for each country, which is a limitation of the study. Also, the non-inclusion of some demand-side determinants like labor cost, distance cost, literacy rate, and political stability, and some of the supply-side determinants like economies of scale or product life cycles, is a limitation of the study. The inclusion of annual data covering only a short period (2004-2018) is a further limitation.

However, our results are reliable and directly comparable using the OLS method in evaluating cross-section data by eliminating the errors that accompanied the data, as well as any correlation (heteroskedasticity) that may be present between observations (see Gorg and Strobl 2001). The use of different models (OLS, Granger Causality) and the combination of results have provided more explanatory power than if we were simply to use only one type of econometric estimation (see Stanley 2001).

In Kosovo, Denmark, and Switzerland, where the values of the Remittances and FDI threshold are with great differences, the impact of Remittances is insignificant in attracting FDI while they are highly correlated between them, an innovation of this study. This result is influenced by both Denmark and Switzerland because remittances are low. Kosovo has a high growth rate of remittances (every year, on average, over $€ 800$ million of remittances come to Kosovo), with $22.5 \%$ of total remittances coming from Switzerland alone (CBK 2018, p. 35). For 20 years, it has promoted economic growth. This increase in remittances in Kosovo has not yet brought foreign investors to Kosovo (it did not exceed $€ 470.4$ million of FDI in 2007). In countries such as Denmark and Switzerland, where remittance rates are low, the impact on economic growth is not significant, and thus it is not a factor in economic growth.

The other innovation of this study is that it combines three diametrically opposed countries with these variables, which has never been done before. 
Such a combination highlighted the importance of FDI and remittance determinants in developing and developed countries. A positive trend of remittances is expected to be in the next decade, based on the global size of the remittance market in 2018, estimated at $\$ 682.6$ billion; forecasts are that they will reach $\$ 930.44$ billion by 2026 (Allied Analytics LLP 2020).

The results of this study will be of interest to Government institutions in Kosovo to improve the business environment, and stimulate capital growth and employment with more professionally qualified workers to be attractive to foreign investors.

\section{References}

Adams Jr, R.H., Page, J. (2005), Do international migration and remittances reduce poverty in developing countries?, "World Development", 33 (10), pp. 1645-1669, https:// doi.org/10.1016/j.worlddev.2005.05.004

Adams, S. (2009), Foreign direct investment, domestic investment, and economic growth in Sub-Saharan Africa, "Journal of Policy Modeling", 31 (6), pp. 939-949, https:// doi.org/10.1016/j.jpolmod.2009.03.003

Adenutsi, D.E. (2014), Macroeconomic Determinants of Workers Remittances and compensation of Employees in Sub-Saharan Africa, "The Journal of Developing Areas", 48 (1), pp. 337-360, https://doi.org/10.1353/jda.2014.0015

Balasubramanyam, V.N., Salisu, M., Sapsford, D. (1996), Foreign direct investment and growth in EP and IS countries, "The Economic Journal", 106 (434), pp. 92-105, https://doi.org/10.2307/2234933

Baldwin, R., Lopez-Gonzalez, J. (2015), Supply-chain trade: A portrait of global patterns and several testable hypotheses, "The World Economy”, 38 (11), pp. 1682-1721, https://doi.org/10.1111/twec.12189

Barajas, A., Chami, R., Fullenkamp, C., Gapen, M., Montiel, P.J. (2009), Do workers remittances promote economic growth?, "IMF Working Papers", 153, pp. 1-22, https:// doi.org/10.5089/9781451873009.001

Basnet, H.C., Upadhyaya, K.P. (2014), Do Remittances Attract Foreign Direct Investment? An Empirical Investigation, "Global Economy Journal”, 14 (1), pp. 1-9, https:// doi.org/10.1515/gej-2013-0052

Beugelsdijk, S., Smeets, R., Zwinkels, R. (2008), The impact of horizontal and vertical FDI on host's country economic growth, "International Business Review", 17 (4), pp. 452-472, https://doi.org/10.1016/j.ibusrev.2008.02.004

Blomstrom, M., Lipsey, R.E., Zejan, M. (1992), What explains developing country growth?, "NBER working paper” (w4132), https://www.nber.org/system/files/wor king_papers/w4132/w4132.pdf (accessed: 11.07.2019).

Borensztein, E., De Gregorio, J., Lee, J.W. (1998), How does foreign direct investment affect economic growth?, "Journal of International Economics", 45 (1), pp. 115-135, https://doi.org/10.1016/S0022-1996(97)00033-0 
Bourdet, Y., Falck, H. (2006), Emigrants” remittances and Dutch disease in Cape Verde, „International Economic Journal”, 20 (3), pp. 267-284, https://doi.org/10.1080/101 68730600879323

Brekke, J.P., Roed, M., Schone, P. (2016), Reduction or deflection? The effect of asylum policy on interconnected asylum flows, "Migration Studies", 5 (1), pp. 65-96, https:// doi.org/10.1093/migration/mnw028

BTI Transformation Index, Kosovo Country Report 2020, https://www.bti-project.org /en/reports/country-report-RKS-2020.html\#pos7 (accessed: 1.08.2020).

Buch, C.M., Kuckulenz, A. (2010), Worker Remittances and Capital Flows to Developing Countries. "International Migration”, 48 (5), pp. 89-117, https://doi.org/10.1111 /j.1468-2435.2009.00543.x

Büthe, T., Milner, H.V. (2008), The politics of foreign direct investment into developing countries: increasing FDI through international trade agreements?, "American Journal of Political Science”, 52 (4), pp. 741-762, https://doi.org/10.1111/j.1540-59 07.2008.00340.x

Carkovic, M., Levine, R. (2005), Does foreign direct investment accelerate economic growth?, "Does Foreign Direct Investment Promote Development”, 195, http://ci teseerx.ist.psu.edu/viewdoc/download?doi=10.1.1.494.5205\&rep=rep1\&type $=$ pdf (accessed: 11.09.2019).

CBK, Central Bank of the Republic of Kosovo (2018), Financial stability report, No. 13, https://bqk-kos.org/repository/docs/2018/BQK_FSR_13.pdf (accessed: 29.03.2020).

CBK, Central Bank of the Republic of Kosovo (2020), Financial Stability Report, No. 15, https://bqk-kos.org/repository/docs/2018/CBK_FSR_15.pdf (accessed: 29.03.2020).

Chami, R., Fullenkamp, C., Jahjah, S. (2003), Are immigrant remittance flows a source of capital for development?, "IMF Working Paper" WP/031189, https://www.elib rary.imf.org/doc/IMF001/00376-9781451859638/00376-9781451859638/Other_for mats/Source_PDF/00376-9781451904994.pdf?redirect=true (accessed: 19.02.2020).

Comes, C.A., Bunduchi, E., Vasile, V., Stefan, D. (2018), The Impact of Foreign Direct Investments and Remittances on Economic Growth: A Case Study in Central and Eastern Europe, “Sustainability”, 10 (1), p. 238, https://doi.org/10.3390/su10010238

Coon, M., Neumann, R. (2016), Follow the Money: Remittance Responses to FDI Inflows, "Journal of Globalization and Development", 8 (2), pp. 1-20, https://doi.org /10.1515/jgd-2017-0023

Czaika, M., Hobolth, M. (2016), Do restrictive asylum and visa policies increase irregular migration into Europe?, "European Union Politics", 17 (3), pp. 345-365, https:// doi.org/10.1177/1465116516633299

Giannetti, M., Federici, D., Raitano, M. (2009), Migrant remittances and inequality in Central-Eastern Europe, "International Review of Applied Economics", 23 (3), pp. 289-307, https://doi.org/10.1080/02692170902811710

Glass, A.J., Saggi, K. (2002), Multinational firms and technology transfer, "Scandinavian Journal of Economics", 104 (4), pp. 495-513, https://doi.org/10.1111/1467-94 42.00298

globalEDGE, https://globaledge.msu.edu (accessed: 18.02.2020).

Global Happiness and Hope Index, https://iiacss.org/global-happiness-and-hope-ind ex/ (accessed: 2.05.2020). 
Gorg, H., Strobl, E. (2001), Multinational companies and productivity spillovers: A metaanalysis, “The Economic Journal”, 111 (475), pp. F723-F739, https://doi.org/10.1111 /1468-0297.00669

Granger, C.W.J. (1969), Investigating Causal Relations by Econometric Models and Cross-Spectral Methods, "Econometrica”, 37 (3), pp. 424-438, https://doi.org/10.23 07/1912791

Haller, A.P., Butnaru, R.C., Butnaru, G.I. (2018), International migrant remittances in the context of economic and social sustainable development. A comparative study of Romania-Bulgaria, "Sustainability", 10 (4), 1156, https://doi.org/10.3390/su1004 1156

Helbling, M., Leblang, D. (2019), Controlling immigration? How regulations affect migration flows, "European Journal of Political Research”, 58 (1), pp. 248-269, https:// doi.org/10.1111/1475-6765.12279

Holtz-Eakin, D., Newey, W., Rosen, H.S. (1988), Estimating vector autoregressions with panel data, "Econometrica: Journal of the Econometric Society", 56 (6), pp. 13711395, https://doi.org/10.2307/1913103

Javorcik, B., Özden, Ç., Spatareanu, M., Constantinescu N.I. (2011), Migrant networks and foreign direct investment, "Journal of Development Economics", 94 (2), pp. 231241, https://doi.org/10.1016/j.jdeveco.2010.01.012

Mehedintu, A., Soava, G., Sterpu, M. (2019), Remittances, Migration and Gross Domestic Product from Romania's Perspective, "Sustainability", 12 (1), pp. 1-19, https://doi .org/10.3390/su12010212

Mottaleb, K.A. (2007), Determinants of foreign direct investment and its impact on economic growth in developing countries, https://mpra.ub.uni-muenchen.de/9457/1/MP RA_paper_9457.pdf (accessed: 2.10.2020).

Palamuleni, M.L. (2018), Do remittances really attract foreign direct investments? Evidence from panel cointegration, "Theoretical and Applied Economics", XXV (4 (617), Winter), pp. 221-234, http://store.ectap.ro/articole/1369.pdf (accessed: 27.12.2019).

Pesaran, M.H., Shin, Y., Smith, R.J. (2001), Bounds testing approaches to the analysis of level relationships, "Journal of Applied Econometrics", 16 (3), pp. 289-326, https://www.repository.cam.ac.uk/bitstream/handle/1810/418/pss1.pdf?s (accessed: 2.10.2020).

Rahman, M.M., Fee, L.K. (2014), Understanding Remittances: Theoretical and Methodological Issues", [in:] Mi. Rahman, T. Yong, A. Ullah (eds.), Migrant Remittances in South Asia, Palgrave Macmillan, Basingstoke, pp. 33-51, https://doi.org/10.1057 /9781137350800_2

Ratha, D. (2013), The impact of remittances on economic growth and poverty reduction, "Policy Brief", 8 (1), pp. 1-13, https://www.migrationpolicy.org/pubs/Remittances -PovertyReduction.pdf (accessed: 27.12.2019).

Saggi, K. (2002), Trade, foreign direct investment, and international technology transfer: A survey, "The World Bank Research Observer”, 17 (2), pp. 191-235, https://doi .org/10.1093/wbro/17.2.191

Stanley, T.D. (2001), Wheat from chaff: Meta-analysis as quantitative literature review, "Journal of Economic Perspectives", 15 (3), pp. 131-150, https://doi.org/10.1257/jep .15 .3 .131 
Switzerland Rated One of the Safest Countries by DKV, https://www.fus.edu/news-e vents/news/1193 (accessed: 14.02.2020).

World Bank Group (2019), World Development Report 2019. The Changing Nature of Work, http://documents1.worldbank.org/curated/en/816281518818814423/pdf/20 19-WDR-Report.pdf (accessed: 2.10.2020).

World Bank Group (2020), World Development Report 2020. Trading for Development in the Age of Global Value Chains, http://documents1.worldbank.org/curated/en/31 0211570690546749/pdf/World-Development-Report-2020-Trading-for-Developme nt-in-the-Age-of-Global-Value-Chains.pdf (accessed: 2.10.2020).

World Happiness Report 2021, https://worldhappiness.report/ (accessed: 14.02.2020). 
Kida Nakije

\section{Annex A}

Table 1a. Descriptive analysis by countries

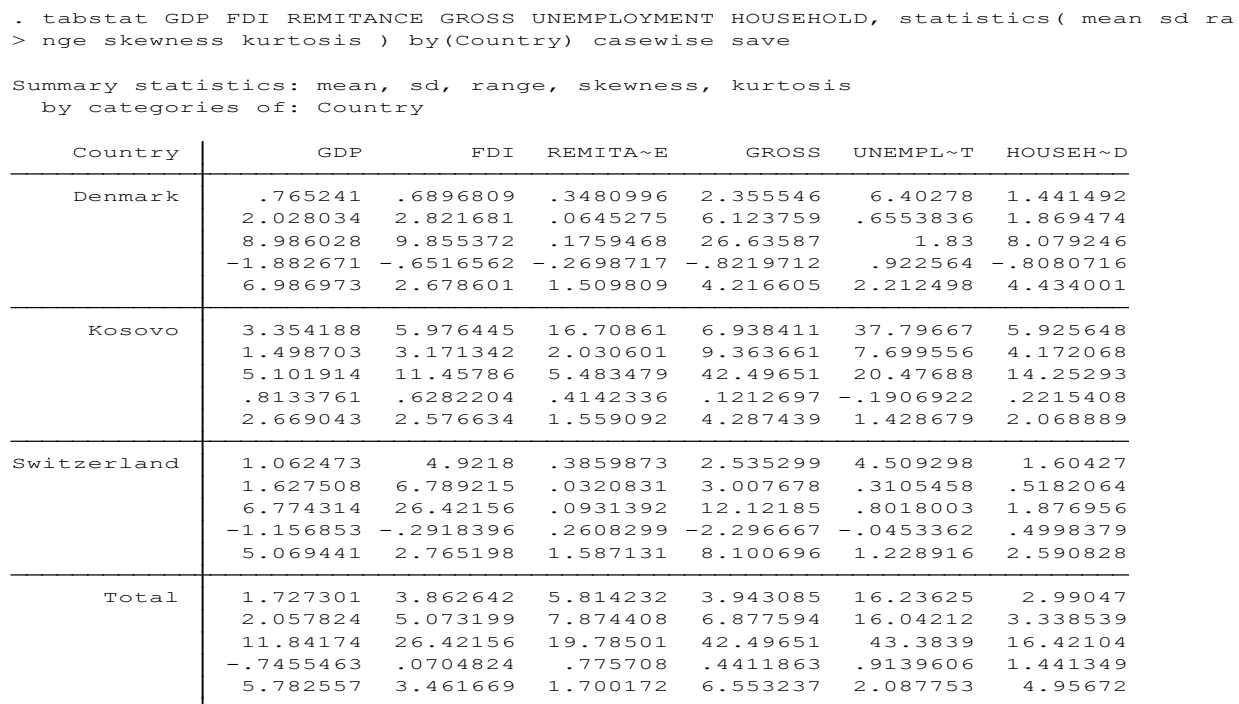

Source: author's own elaboration.

\section{Annex B}

\section{The Anova One Way is used to compare the three countries}

Table 1b. Difference between the three countries regarding FDI

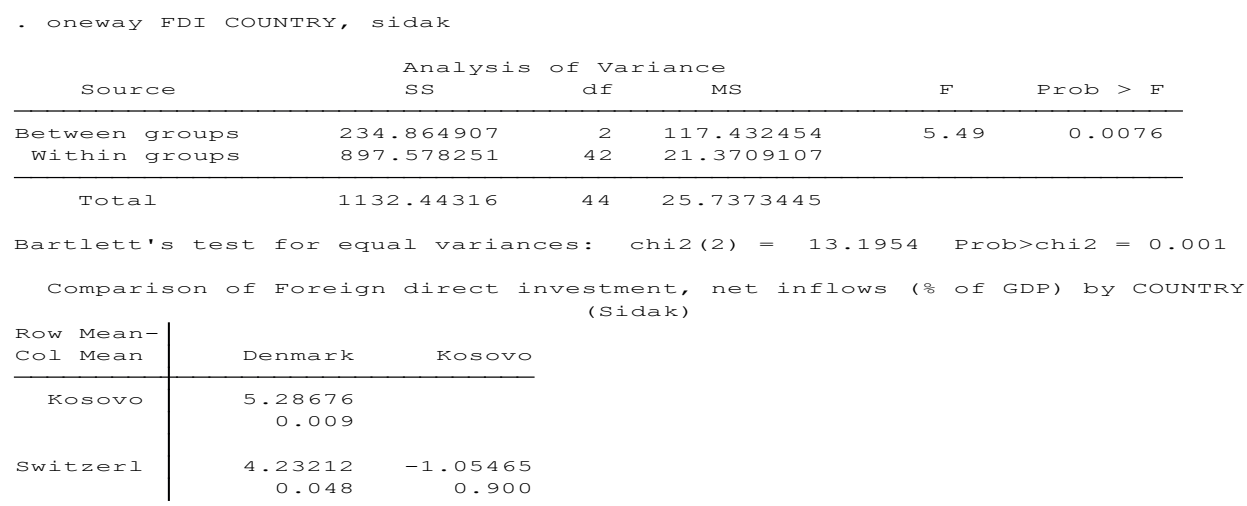

Source: author's own elaboration. 
Table 1c. Difference between the three countries regarding remittances

- oneway REMITANCE COUNTRY, sidak

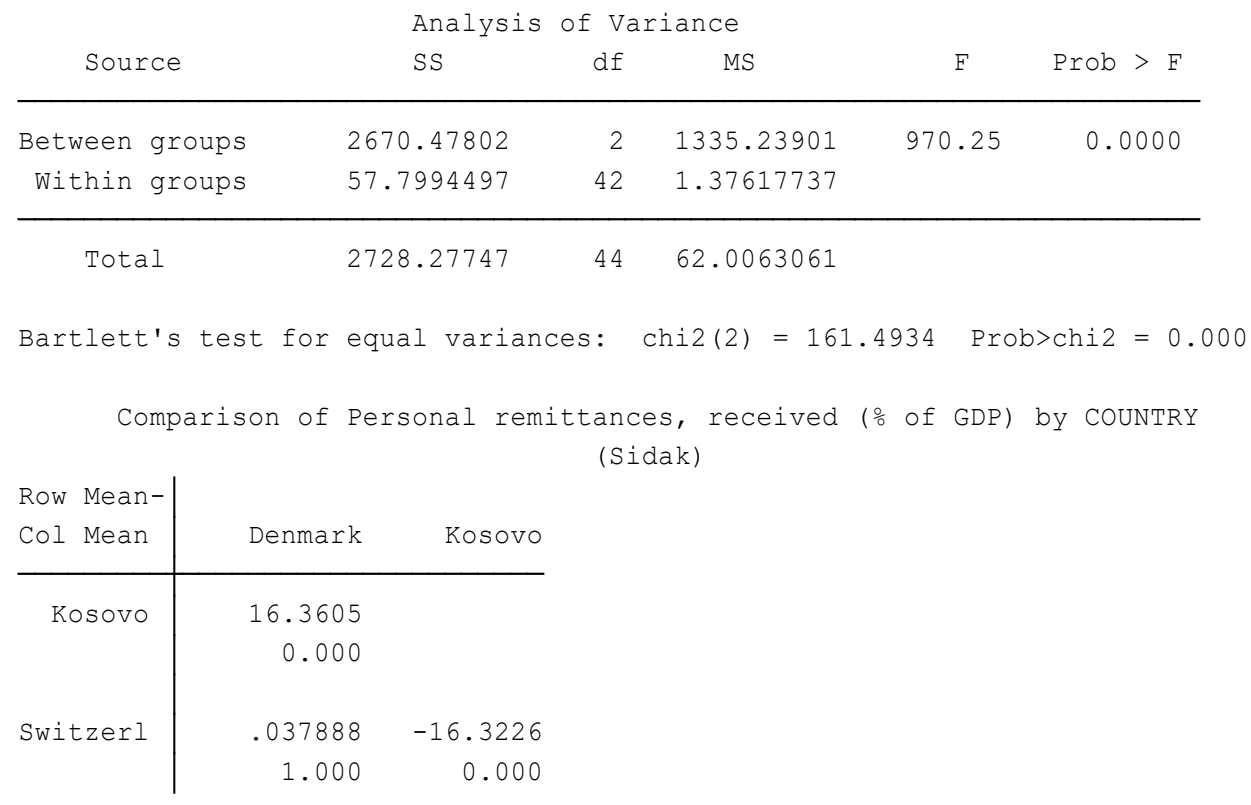

Source: author's own elaboration.

Table 8a. Granger causaliy test

- var GDP FDI REMITANCE GROSS, $\operatorname{lags}(1 / 2)$

\begin{tabular}{|c|c|c|c|c|c|}
\hline \multirow{2}{*}{\multicolumn{4}{|c|}{$\begin{array}{l}\text { Sample: } 2006-2018 \\
\text { Log likelihood }=-20.15079\end{array}$}} & \multicolumn{2}{|c|}{ No. of obs } \\
\hline & & & & \multicolumn{2}{|c|}{ AIC } \\
\hline FPE & $=.238736$ & & & \multicolumn{2}{|l|}{ HQIC } \\
\hline Det (Sigma_ml) & $=.000260$ & & & \multicolumn{2}{|l|}{ SBIC } \\
\hline Equation & Parms & RMSE & $R-s q$ & chi2 & $\mathrm{P}>\mathrm{chi} 2$ \\
\hline GDP & 9 & .885914 & 0.8689 & 86.13579 & 0.0000 \\
\hline FDI & 9 & 3.50208 & 0.5552 & 16.22367 & 0.0393 \\
\hline REMITANCE & 9 & .073802 & 0.9960 & 3231.122 & 0.0000 \\
\hline GROSS & 9 & 3.10191 & 0.7548 & 40.01281 & 0.0000 \\
\hline
\end{tabular}

Source: author's own elaboration. 


\section{Związek przyczynowy między BIZ a przekazami pieniężnymi w Kosowie, Szwajcarii i Danii}

Pogoń za pieniędzmi i kapitałem jest nieustannym dążeniem każdej gospodarki. BIZ są uważane za siłę napędową wzrostu gospodarczego, podczas gdy przekazy pieniężne są w coraz większym stopniu katalizatorem dobrobytu ludności. Celem opracowania jest analiza związku między przekazami pieniężnymi a napływem BIZ do Kosowa, Szwajcarii i Danii. Wtórne dane uzyskane z opracowania World Development Indicators zostały przeanalizowane za pomocą metody zwykłych najmniejszych kwadratów i testu przyczynowości Grangera oraz przetworzone techniką SPSS 21. Pomiar korelacji między zmiennymi: bezpośrednimi inwestycjami zagranicznymi, wzrostem PKB per capita, saldem migracji, przekazami pieniężnymi, nakładami brutto na środki trwałe, spożyciem gospodarstw domowych i liczbą ludności, daje wiarygodne wyniki. Wykorzystując przekazy pieniężne jako zmienną zależną, pierwsza hipoteza została częściowo potwierdzona. Najbardziej istotne statystycznie determinanty zwiększające przekazy pieniężne to populacja, bezrobocie i migracje. Wyniki regresji są niezadowalające w przypadku zmiennej zależnej BIZ (druga hipoteza). Determinanty są skorelowane pozytywnie, ale nieistotnie statystycznie, co potwierdza, że istnieją inne czynniki wpływające na wzrost napływu BIZ. Macierz korelacji wykazuje wysoką korelację między zmiennymi. Model przyczynowości Grangera, poprzez test Walda, reprezentuje przyczynę tego zjawiska. BIZ nie generują przekazów pieniężnych, ale przekazy pieniężne wpływają na wielkość BIZ. Ograniczeniem badania jest niejednorodność danych i krajów w próbie. Wyniki badania będą posłużyć instytucjom rządowym w Kosowie do poprawy otoczenia biznesowego, tak aby kraj stał się atrakcyjny dla inwestorów zagranicznych, dzięki którym nastąpi wzrost kapitału i zatrudnienia.

Słowa kluczowe: FDI, przekazy pieniężne, dane panelowe, OLS, przyczynowość Grangera 